\title{
Effects of river floodplain lowering and vegetation cover
}

\author{
J. A. Villada Arroyave MSc and A. Crosato PhD
}

The current river management policy in the Netherlands is to give rivers more space, mainly by main channel widening and floodplain lowering. The aim is to reduce flood water levels and to create more favourable conditions for river ecology. However, the effect on water levels gradually disappears due to sedimentation and vegetation growth on floodplains. The key questions are how effective these measures are and how long the desired effect remains. A two-dimensional, depthaveraged, morphological model was applied to the Meers pilot project on the Common Meuse River. The project consisted of channel widening by floodplain excavation, carried out over a short reach. Spatially varying floodplain vegetation was included. The results showed that the pilot project would be effective in lowering local water levels during a period of $\mathbf{2 0}$ years for floods having a return period of $\mathrm{I}-4$ years but not for floods having a return period of 100 years. In the latter case, water levels would be dominated by a restriction in floodplain width, causing backwater effects. Floodplain vegetation was found to shorten the lifetime of the project by enhancing sedimentation.

\section{NOTATION}

$C_{\mathrm{b}} \quad$ bed roughness expressed by the Chézy coefficient $\left(\mathrm{m}^{1 / 2} / \mathrm{s}\right)$

$C_{\mathrm{D}} \quad$ drag coefficient (-)

$C_{\mathrm{r}} \quad$ Chézy coefficient $\left(\mathrm{m}^{1 / 2} / \mathrm{s}\right)$ that is representative for the resistance to the flow through partially submerged vegetation

$C_{\mathrm{rs}} \quad$ Chézy coefficient $\left(\mathrm{m}^{1 / 2} / \mathrm{s}\right)$ that is representative for the total resistance to the flow for fully submerged vegetation cylinder (stem) diameter $(\mathrm{m})$ bed erosion rate in $\left(\mathrm{kg} / \mathrm{m}^{3}\right) / \mathrm{s}$ acceleration due to gravity $\left(\mathrm{m} / \mathrm{s}^{2}\right)$ water depth $(\mathrm{m})$ longitudinal water surface slope (-) height of plants $(\mathrm{m})$ erosion coefficient in $\left(\mathrm{kg} / \mathrm{m}^{2}\right) / \mathrm{s}$ cylinder (plant) density per unit area $\left(1 / \mathrm{m}^{2}\right)$ flow velocity through vegetation $(\mathrm{m} / \mathrm{s})$ reach-averaged value of flow velocity $(\mathrm{m} / \mathrm{s})$ van Kármán constant $(\kappa=0 \cdot 4)$ mass density of water $\left(\mathrm{kg} / \mathrm{m}^{3}\right)$ bed shear stress $\left(\mathrm{N} / \mathrm{m}^{2}\right)$ critical bed shear stress for erosion $\left(\mathrm{N} / \mathrm{m}^{2}\right)$ $\begin{array}{ll}\boldsymbol{T}_{\mathrm{bc}} & \text { critical } \\ \boldsymbol{T}_{\mathrm{v}} & \text { shear stress caused by vegetation }\left(\mathrm{N} / \mathrm{m}^{2}\right)\end{array}$

\section{INTRODUCTION}

For many rivers in Europe floods might be more severe in the future, due to climate change and changes in land use, whereas flood protection cannot be achieved by continuous raising of dykes. Therefore, new trends in river management aim at lowering flood levels by allowing more space to the river. This, together with the need to restore lost riverine ecosystems, results in river restoration projects that allow for some natural processes, such as controlled sedimentation and erosion (Baptist, 2005). The new strategies for river restoration and flood management comprise river widening, the lowering of floodplains and excavation of secondary channels.

Recent restoration projects in the Netherlands show a successful increase of fluvial biodiversity (e.g. Buijse et al., 2002; Raat, 2001), but there is increasing concern over floodplain vegetation growth and its effects on the flood conveyance of the river.

Floodplain vegetation depends on the river hydraulic regime and dynamics, such as the frequency of floods and the formation of new sediment deposits (e.g. Franz and Bazzaz, 1977; Hupp and Osterkamp, 1996; Johnson, 1998; Merritt and Cooper, 2000). In turn, floodplain vegetation influences the river morphodynamic trends, by locally increasing the resistance to the flow while also reducing soil erodibility (e.g. Carollo et al., 2002; Corenblit et al., 2007; Thorne, 1990; Tsujimoto, 1999). As a consequence, due to floodplain vegetation the flood levels increase and the flow velocities decrease on the floodplains, but increase in the main river channel. Due to vegetation growth and morphological processes, such as sedimentation and erosion, the positive effects of river restoration works gradually vanish and, for this reason, restored rivers may require regular maintenance (Brookes, 1990). In order to assess the effectiveness and duration of restoration works it is therefore necessary to study the long-term morphological evolution of the river, taking into account the effects of floodplain vegetation.

In the present study the effectiveness of the restoration works carried out on the gravel-bed Common Meuse River at Meers (the Netherlands) in the short and long term was investigated. A two-dimensional (2D) depth-averaged morphological model taking into account the effects of spatially-variable vegetation and bank erosion was used, incorporating a graded-sediment approach, with sand to gravel in the main channel and medium 
silt on the floodplains. The effects of vegetation on hydraulic roughness were taken into account using the method proposed by Baptist (2005), which distinguishes between soil and plant resistance and between fully and partially submerged vegetation. The effects of vegetation on soil resistance were simulated by adapting the critical shear stress for erosion and the erosion speed of the floodplain soil. For the sake of simplicity, plant succession (e.g. Elgersma, 1998) was not taken into account.

\section{CASE STUDY}

The Common Meuse is part of the middle course of the River Meuse, between Maastricht and Stevensweert (south-west Netherlands). This river reach is $45 \mathrm{~km}$ long and constitutes the natural border between the Netherlands and Belgium (Figure 1). The Common Meuse River is the only gravel-bed river in the Netherlands and for this reason its bed has often been excavated in the past to provide material for construction. Unfortunately no records of the extracted volumes are available.

Major flood events have occurred in the last two decades and indicate an important variation in the river regime, which is possibly due to changes of soil use in the catchment area and to climatic changes. The floods, which occurred in 1993 and 1995, caused considerable social and economic damage and led to the development of a new river management strategy with the aim of protecting the inhabitants against floods and simultaneously increasing the ecological value of the river (Olsthoorn and Tol, 2001). This new strategy resulted in the Common Meuse project, consisting of main channel widening and deepening as well as floodplain lowering (Figure 2) at given locations, to increase both the conveyance capacity of

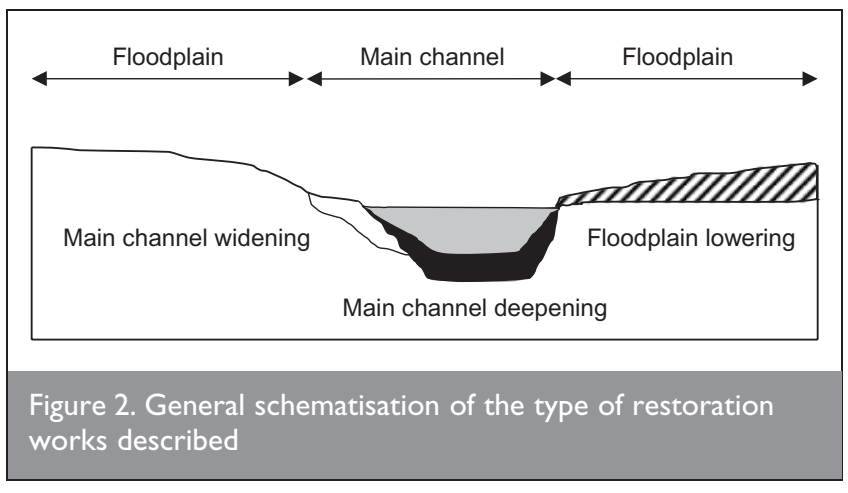

the river during floods and the potential for the development of a natural ecological environment (Klaassen et al., 1998).

The Common Meuse project includes some pilot studies, such as the Meers pilot project, which was carried out in 2002 near the village of Meers (Figure 3). This pilot project mainly consisted of widening of the local main channel by lowering the right river floodplain in the part adjacent to the main river channel. The total volume of extracted sediment was $435000 \mathrm{~m}^{3}$.

At Meers, the river has a meandering planform. The main channel is characterised by the presence of alternate bars, point bars and, occasionally, central bars, and the floodplain vegetation varies from grass to trees (Figure 4). The river bed is armoured most of the time. The armour layer, which consists of gravel with diameters between 10 and $100 \mathrm{~mm}$ (Sharef, 2006), is mobilised by a flow discharge of $1250 \mathrm{~m}^{3} / \mathrm{s}$, which corresponds to the bankfull discharge. The discharge

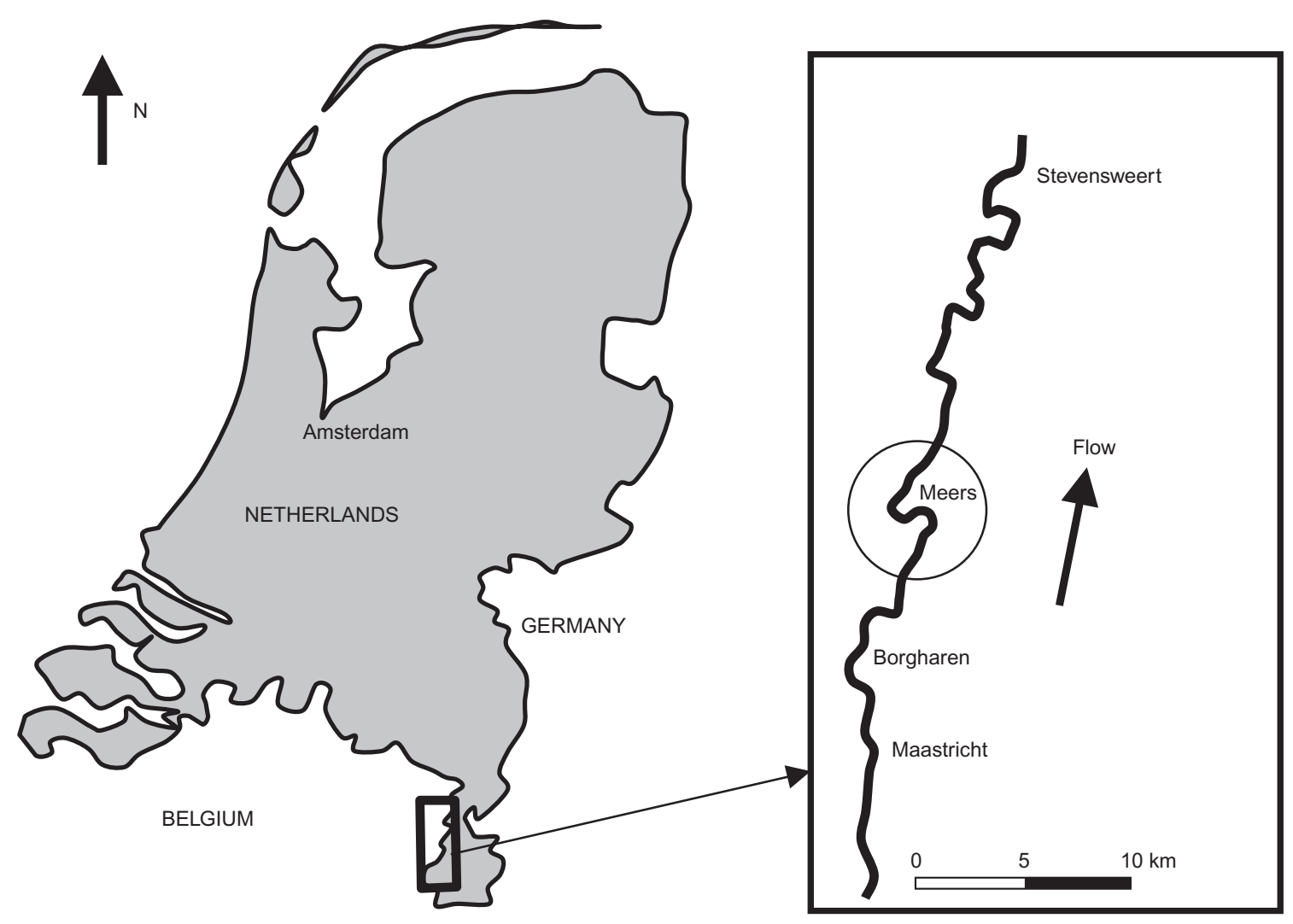

Figure I. General localisation of the Common Meuse River: circle identifies the study area 

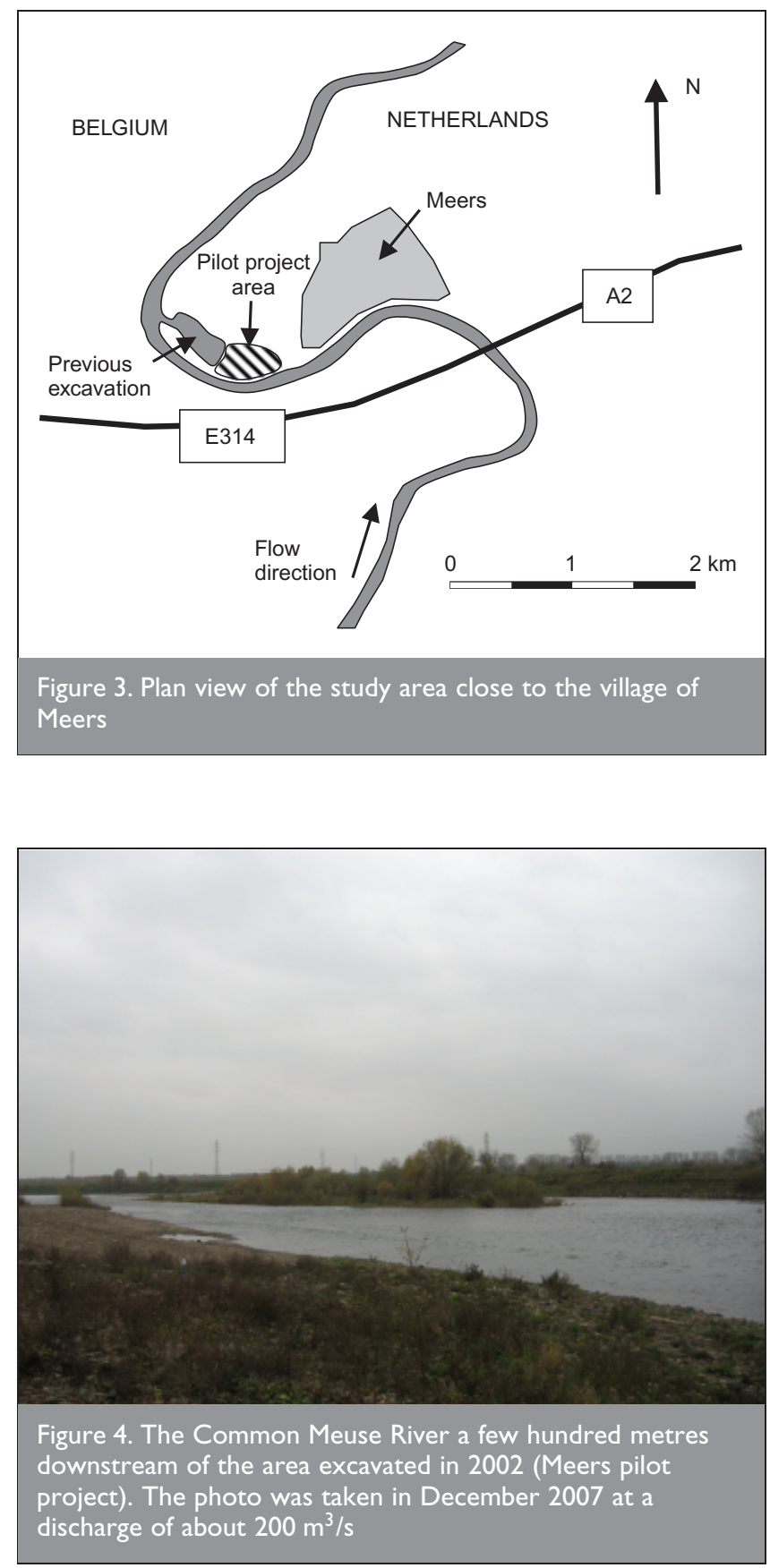

characteristics at Borgharen, $15 \mathrm{~km}$ upstream of Meers, are summarised in Table 1 and the main characteristics of the river in the study area are listed in Table 2.

This paper deals with the assessment of the short- and longterm effects of the Meers pilot project over a $14 \mathrm{~km}$ long river reach, focusing on the main river channel, with the aim of deriving some guidelines for the extension of the work to the entire Common Meuse project.

\section{MATERIALS AND METHODS}

\section{I. Model description}

The long-term morphological trends of the river in the study area were analysed by means of a fully non-linear, timedependent, physics-based morphological model. In this model, the three-dimensional Navier-Stokes equations for incompressible fluid and shallow water (Lesser et al., 2004) are coupled to the balance and transport equations for sediment, all designed for curved channels. The computations were carried out using a 2D depth-averaged version of the model with an appropriate parameterisation of relevant 3D effects. In this case, the model accounts for two effects of the spiral motion that arises in curved flow (e.g. Blanckaert et al., 2002). First, the model corrects the direction of sediment transport through a modification in the direction of the bed shear stress, which would otherwise coincide with the direction of the flow velocity vector. Second, the model includes the effects of the transverse flow convection, causing transverse redistribution of main flow velocity, through a correction in the bed friction term. The model accounts for the effects of longitudinal and transverse bed slopes on bed load direction (Bagnold, 1966; Ikeda, 1982; Struiksma et al., 1985). The closure scheme for turbulence is a $k-\varepsilon$ model, in which $k$ is the turbulent kinetic energy and $\varepsilon$ is the turbulent dissipation.

The model allows for separate sediment transport calculations for different sediment sizes, with one mixing layer. Bank erosion is simulated in a simplified way: the model assigns a part of the erosion occurring inside the wet cells that are located at the margin of the water flow to their adjacent dry cells, which then become wet (van der Wegen et al., 2008). In physical terms, this means relating bank erosion to the erosion at the toe of the bank. This bank erosion formulation allows the imposition of a constant bank slope to the entire model domain by adjusting the value of a coefficient. The effects of vegetation on hydraulic roughness were obtained by applying the method developed by Baptist (2005). This method separates the bed shear stress from the shear stress of vegetation and distinguishes between fully and partially submerged vegetation. Plants are schematised as thin, vertical rigid cylinders with given density, height, diameter and the resistance force is modelled opposite to the drag force on a random or staggered array of cylinders with uniform properties. The method also assumes that the flow velocity through the plants is uniformly distributed, which is only valid for high vegetation density. The model is based on the following relation

\begin{tabular}{|l|l|}
\hline $\mathrm{I}$ & $\rho \boldsymbol{g h h i}=\boldsymbol{T}_{\mathrm{b}}+\boldsymbol{T}_{\mathrm{v}}$ \\
\hline
\end{tabular}

\begin{tabular}{|lcccccc|}
\hline Min.: $\mathrm{m}^{3} / \mathrm{s}$ & Max:: $\mathrm{m}^{3} / \mathrm{s}$ & Mean: $\mathrm{m}^{3} / \mathrm{s}$ & Bankfull: $\mathrm{m}^{3} / \mathrm{s}$ & $\begin{array}{c}\text { Min. value to move the } \\
\text { armour layer: } \mathrm{m}^{3} / \mathrm{s}\end{array}$ & $\begin{array}{c}\text { Yearly flood discharge } \\
\text { last } 95 \text { years: } \mathrm{m}^{3} / \mathrm{s}\end{array}$ & $\begin{array}{c}\text { Yearly flood discharge } \\
\text { last I5 years: } \mathrm{m}^{3} / \mathrm{s}\end{array}$ \\
\hline 25 & $3000^{*}$ & 245 & 1250 & 1250 & 1460 & 1683 \\
\hline * Return period about one century & & & & \\
\hline
\end{tabular}




\begin{tabular}{|c|c|c|c|c|c|c|c|c|}
\hline \multirow[t]{2}{*}{$\begin{array}{l}\text { Main channel } \\
\text { width: } \mathrm{m}\end{array}$} & \multicolumn{2}{|c|}{$\begin{array}{l}\text { Min. floodplain } \\
\text { width: } \mathrm{m}\end{array}$} & \multicolumn{2}{|c|}{$\begin{array}{l}\text { Max. floodplain } \\
\text { width: } m\end{array}$} & \multirow[t]{2}{*}{$\begin{array}{l}\text { Long. bed } \\
\text { slope }\end{array}$} & \multirow[t]{2}{*}{$\begin{array}{l}\text { Main channel } \\
D_{50}: \mathrm{mm}\end{array}$} & \multirow[t]{2}{*}{$\begin{array}{l}\text { Main channel } \\
D_{90}: \mathrm{mm}\end{array}$} & \multirow[t]{2}{*}{$\begin{array}{l}\text { Bulk* sediment } \\
\text { transport: } \mathrm{m}^{3} / \text { year }\end{array}$} \\
\hline & Left & Right & Left & Right & & & & \\
\hline 80 & 324 & 386 & 833 & 1617 & 0.00045 & 38 & 70 & 50000 \\
\hline
\end{tabular}

* This volume includes pores.

Table 2. Main river characteristics in the study area

in which $\rho$ is the mass density of water $\left(\mathrm{kg} / \mathrm{m}^{3}\right) ; \boldsymbol{g}$ is the acceleration due to gravity $\left(\mathrm{m} / \mathrm{s}^{2}\right) ; h$ is the water depth $(\mathrm{m}) ; i$ is the longitudinal water surface slope $(-) ; \boldsymbol{T}_{\mathrm{b}}$ is the bed shear stress $\left(\mathrm{N} / \mathrm{m}^{2}\right)$; and $\boldsymbol{T}_{\mathrm{v}}$ is the shear stress caused by vegetation $\left(\mathrm{N} / \mathrm{m}^{2}\right)$.

In case of uniform flow through partially submerged vegetation, the water depth is smaller than the height of plants and the flow velocity through the plants coincides with the reach-averaged velocity. In this case

$\boldsymbol{T}_{\mathrm{b}}=\frac{\rho \boldsymbol{g}}{C_{\mathrm{b}}^{2}} \boldsymbol{u}_{\mathrm{c}}^{2}=\frac{\rho \boldsymbol{g}}{C_{\mathrm{b}}^{2}} \overline{\boldsymbol{u}}^{2}$

and

$$
3 \quad \boldsymbol{T}_{\mathrm{v}}=\frac{1}{2} \rho C_{\mathrm{D}} m D h \boldsymbol{u}_{\mathrm{c}}^{2}=\frac{1}{2} \rho C_{\mathrm{D}} m D h \overline{\boldsymbol{u}}^{2}
$$

in which $C_{\mathrm{b}}$ is the bed roughness expressed by the Chézy coefficient $\left(\mathrm{m}^{1 / 2} / \mathrm{s}\right) ; \boldsymbol{u}_{\mathrm{c}}$ is the flow velocity through vegetation $(\mathrm{m} / \mathrm{s}) ; \bar{u}$ is the reach-averaged value of flow velocity $(\mathrm{m} / \mathrm{s}) ; C_{D}$ is the drag coefficient $(-) ; m$ is the cylinder (plant) density per unit area $\left(1 / \mathrm{m}^{2}\right)$; and $D$ is the cylinder (stem) diameter $(\mathrm{m})$.

For partially submerged vegetation the flow can be described by the following Chézy relation

4

$$
\overline{\boldsymbol{u}}=C_{\mathrm{r}} \sqrt{h i}
$$

in which $C_{\mathrm{r}}$ is the Chézy coefficient $\left(\mathrm{m}^{1 / 2} / \mathrm{s}\right)$ that is representative for the resistance to the flow through partially submerged vegetation, which, by combining Equations 2 and 3 and taking into account that $\boldsymbol{u}_{\mathrm{c}}=\overline{\boldsymbol{u}}$, is given by

$5 \quad C_{\mathrm{r}}=\sqrt{\frac{1}{\frac{1}{C_{\mathrm{b}}^{2}}+\frac{C_{\mathrm{D}} m D h}{2 \mathfrak{g}}}}$

For fully submerged vegetation the water depth is larger than the height of plants. In this case it is assumed that the flow velocity is uniform between the plants but has a logarithmic profile above them, starting from the value $\boldsymbol{u}_{\mathrm{c}}$, which is given by

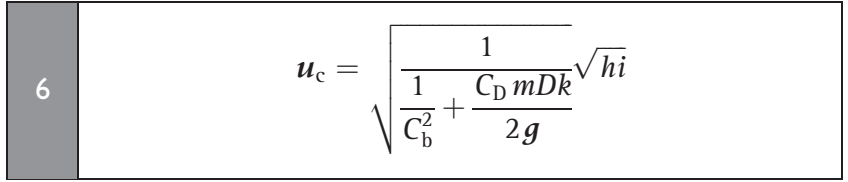

in which $k$ is the height of plants (m).

For fully submerged vegetation

\begin{tabular}{|l|l|}
\hline 7 & $\boldsymbol{T}_{\mathrm{b}}=\frac{\rho \boldsymbol{g}}{C_{\mathrm{b}}^{\prime 2}} \overline{\boldsymbol{u}}^{2}$ \\
\hline
\end{tabular}

with

\begin{tabular}{|l|l|}
\hline 8 & $C_{\mathrm{b}}^{\prime}=C_{\mathrm{b}}+\frac{\sqrt{\boldsymbol{g}}}{\kappa} \sqrt{1+\frac{C_{\mathrm{D}} m D k C_{\mathrm{b}}^{2}}{2 \boldsymbol{g}}} \ln \left(\frac{h}{k}\right)$ \\
\hline
\end{tabular}

in which $\kappa$ is the van Kármán constant $(\kappa=0 \cdot 4)$.

For the total flow, that is, the flow through vegetation plus the flow over fully submerged vegetation

\begin{tabular}{|c|c|}
\hline 9 & $\overline{\boldsymbol{u}}=C_{\mathrm{rs}} \sqrt{h i}$ \\
\hline
\end{tabular}

with

$$
C_{\mathrm{rs}}=\sqrt{\frac{1}{\frac{1}{C_{\mathrm{b}}^{2}}+\frac{C_{\mathrm{D}} m D k}{2 \boldsymbol{g}}}}+\frac{\sqrt{\boldsymbol{g}}}{\kappa} \ln \left(\frac{h}{k}\right)
$$

In Equation 10, the first term on the right-hand side equals the representative roughness for partially submerged vegetation if $h=k$. The value of $C_{\mathrm{rs}}$ is larger than the value of $C_{\mathrm{r}}$, which means that fully submerged vegetation offers smaller resistance to the flow than partially submerged vegetation, which is according to expectations.

Coarse sediment transport is computed using a chosen transport capacity formula, in which, in general, the sediment transport rate is determined as a function of $\boldsymbol{T}_{\mathrm{b}}$. In presence of vegetation, $\boldsymbol{T}_{\mathrm{b}}$ is computed using either Equation 2 (partially submerged vegetation) or Equation 7 (fully submerged vegetation). This method leads to a reduction of the sediment 
transport capacity in vegetated areas, which is in agreement with observations (Corenblit et al., 2007).

The entrainment speed of fine cohesive sediment per unit of bed surface is determined using the formula (Partheniades, 1965)

\begin{tabular}{|l|l|}
\hline I & $E=M\left(\frac{\boldsymbol{T}_{\mathrm{b}}}{\boldsymbol{T}_{\mathrm{bc}}}-1\right)$ \\
\hline
\end{tabular}

in which $E$ is the bed erosion rate in $\mathrm{kg} / \mathrm{m}^{3}$ per s, $M$ is the erosion coefficient in $\mathrm{kg} / \mathrm{m}^{2}$ per $\mathrm{s}$ and $\boldsymbol{T}_{\mathrm{bc}}$ is the critical bed shear stress for erosion.

The sedimentation rate of fine material is determined as the near-bed concentration multiplied by the fall velocity.

\subsection{Model set-up}

The modelled area is shown in Figure 5. The sediment on the main river channel bed was subdivided into five sediment fractions, from sand to gravel (Sharef, 2006), whereas the soil of the river floodplains was medium silt, which was treated as cohesive. The adopted sediment characteristics are listed in Table 3. In the main (gravel-bed) channel, the sediment transport capacity was computed using the Meyer-Peter and Müller (1948) formula. The sediment transport on the floodplains (silt) was described by the van Rijn (1993) formula. Here, the reduction of soil erodibility by vegetation was obtained by increasing the critical shear stress for erosion and decreasing the soil erosion coefficient weighting the erosion speed. The critical shear stress, $\boldsymbol{T}_{\mathrm{bc}}$, for bare soil was $0.5 \mathrm{~Pa}$; and for soil between plants $1.5 \mathrm{~Pa}$. The erosion coefficient, $M$, was $6 \times 10^{-4}$ and $4 \times 10^{-4} \mathrm{~kg} / \mathrm{m}^{2}$ per s, respectively. These values were chosen on the basis of previous experience.

For the runs in which the floodplains were assumed to be covered by vegetation, the computation of the hydraulic resistance was based on the spatial distribution of floodplain vegetation measured in 2007. Due to lack of data on vegetation growth and succession in the area, the vegetation characteristics were assumed to remain constant with time, in particular vegetation was not assumed to grow in the excavated area. This is not far from reality, since this area is often inundated with a relatively high flow velocity and has a gravel bed, with the result that only sparse pioneer plants can grow on it. The computed effects of floodplain vegetation on future water levels are affected by these simplifications. This means that the results only provide an indication of their order

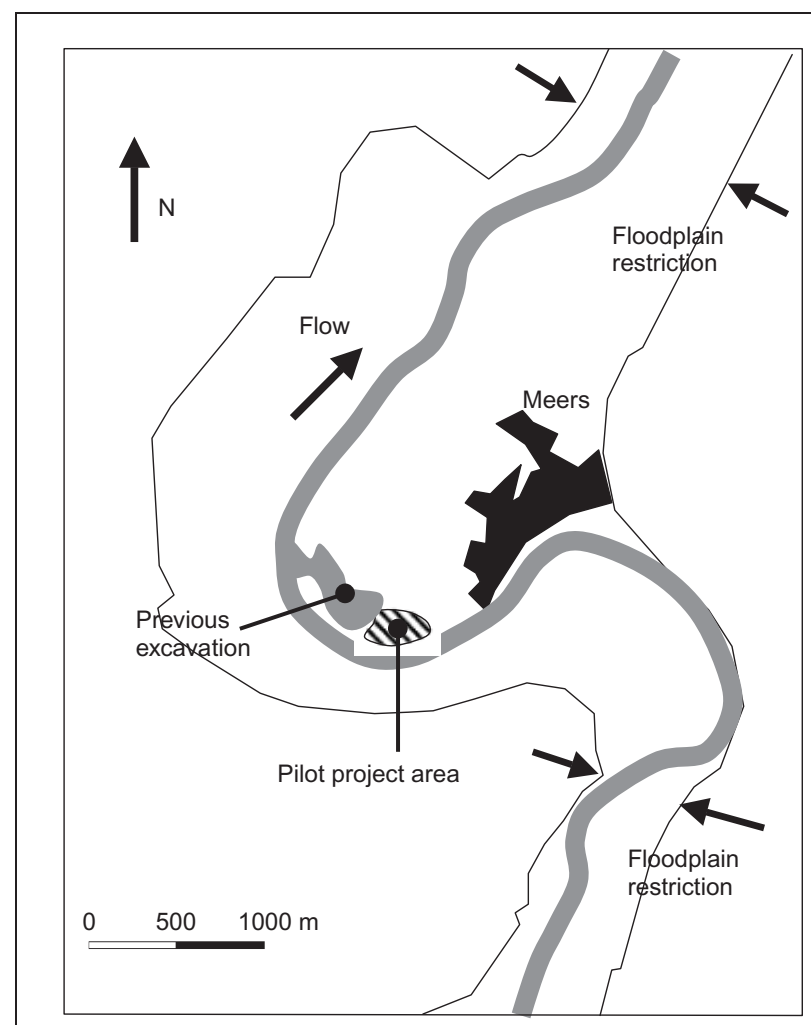

Figure 5. Study area showing the variability of floodplain width

of magnitude. Table 4 lists the characteristics of the vegetation types used in the model. Vegetation cover was imposed on the entire study reach assuming its characteristics in 2007.

To assess the future long-term morphological trends, the discharge regime was simplified into a 'typical hydrological year'. This was derived from the time series of daily discharge measured at Borgharen (Figure 1) in the period 1911-2006.

The morphological computations included only the discharges that can either mobilise the armour layer protecting the main channel bed or produce overbank flow, namely those discharges that were larger than about $1000 \mathrm{~m}^{3} / \mathrm{s}$. Based on the duration curve, discharges greater than $1000 \mathrm{~m}^{3} / \mathrm{s}$ were only present during 10 days per year on average. The highest value of recorded discharge is $3000 \mathrm{~m}^{3} / \mathrm{s}$. In the model, this value was assumed to have a duration of 1 day per year, which corresponds to the situation of the last 15 years. The choice is justified by the recent increase in peak discharges, which is mainly due to changes in soil use in the upper catchment (Pfister et al., 2004), as the model was used to predict the next 20 years.

\begin{tabular}{|c|c|c|c|c|c|}
\hline \multicolumn{3}{|c|}{ Main channel bed } & \multicolumn{3}{|c|}{ Floodplain soil } \\
\hline Class & Min. size: $\mathrm{mm}$ & Max. size: $\mathrm{mm}$ & Class & Size: mm & Fall velocity: $\mathrm{mm} / \mathrm{s}$ \\
\hline I & 0.2 & 3 & Medium silt & 0.031 & I \\
\hline 2 & 3 & 8 & & & \\
\hline 3 & 8 & 22 & & & \\
\hline 4 & 22 & 42 & & & \\
\hline 5 & 42 & 110 & & & \\
\hline
\end{tabular}




\begin{tabular}{|c|c|c|c|c|}
\hline Vegetation & Diameter: m & Density: $1 / \mathrm{m}^{2}$ & Height: $m$ & Drag coefficient \\
\hline Production grass land & 0.003 & 15000 & 0.06 & 1.8 \\
\hline Natural grass land & 0.003 & 4000 & 0.1 & 1.8 \\
\hline Softwood shrub & 0.034 & $3 \cdot 8$ & 6 & 1.5 \\
\hline Herbaceous reed vegetation & 0.005 & 32 & 2 & 1.8 \\
\hline Dry herbaceous vegetation & 0.005 & 46 & 0.56 & 1.8 \\
\hline Herbaceous natural grassland & 0.003 & 5000 & 0.2 & 1.8 \\
\hline Hardwood forest & 0.115 & 0.2 & 10 & 1.5 \\
\hline Softwood forest & 0.140 & 0.2 & 10 & 1.5 \\
\hline
\end{tabular}

As time series data of water levels and discharges were not available, the model was calibrated by comparison with the results of another well-calibrated hydrodynamic model (Sharef, 2006) based on the prediction of water levels during single flood events and by the comparison between results and observed flow characteristics at bankfull discharge (Klaassen, 1981). This calibration concerned the value of the Chézy coefficient, weighing the bed roughness. Several runs were carried out to optimise the time step, based on the accuracy of the results. The final value of the Chézy coefficient was $45 \mathrm{~m}^{1 / 2} / \mathrm{s}$ and the time step was $12 \mathrm{~s}$. As the computational grid is curvilinear, the size of the grid cells was variable with space. Table 5 lists the characteristic sizes of the computational grid cells, for the different morphological zones.

The performance of the model, for the prediction of bed level changes, was assessed by comparing the morphological predictions for the period 2002-2007 with the morphological characteristics in 2007 (validation). No detailed data on river bed levels were available, so validation could only be based on rough information from the field and one satellite image. The model well reproduced the position and extension of the point bars and of the central bar located a few hundred metres downstream of the area excavated in 2002 (Figure 4).

Furthermore, the model predicted patterns of erosion and sedimentation that were qualitatively similar to the observed ones (Villada Arroyave, 2008). If quantitative historical data on bed level changes are missing, as in this case, the results can only be interpreted in a qualitative way, based on 'orders of magnitude'.

The model was finally used to predict the following aspects.

(a) The morphological changes of the river after the execution of the Meers pilot project, which was carried out in 2002. In this case the investigations are labelled 'with project' (WP).

(b) The (hypothetical) river morphological changes that could

\begin{tabular}{|lcc|}
\hline Location & $\Delta X: \mathrm{m}$ & $\Delta Y: \mathrm{m}$ \\
\hline Main channel & 10 & 10 \\
Floodplain & 92 & 93 \\
Floodplain bends & 8 & 75 \\
& \multicolumn{2}{|c|}{} \\
\hline Table 5. Characteristic sizes of computational grid cells \\
\hline
\end{tabular}

be expected if the Meers pilot project had not been executed (reference scenario). In this case the investigations are labelled 'without project' (WOP).

For the latter case (WOP) the latest data available regard the river characteristics in 1998, as no measurements had been made in 2002 before the execution of the project. However, in order to be able to compare the two cases, all simulations should start at the same year. For this reason, a first set of simulations was carried out to compute the river morphology in 2007. One simulation computed the river morphology in 2007 for the hypothetical case WOP and covered the period 1998-2007. Another simulation computed the river morphology in 2007 for the case WP and covered the period 2002-2007. In both cases, the model considered the 2007 floodplain vegetation cover, as no information was available on vegetation cover in the preceding years. This allowed two different river configurations to be obtained for the year 2007, one representing the (modelled) present river configuration and the other one representing how the river would have been in 2007 if the project had not been carried out. The former is the simulation that was used to assess (qualitatively) the model performance (validation, see above).

Starting from the computed river characteristics in 2007, the long-term morphological predictions covered the period 2007 2027. Two scenarios were studied: $(a)$ with spatially-variable floodplain vegetation; and $(b)$ without floodplain vegetation (Figure 6). This allowed the effects of floodplain vegetation and of the Meers pilot project on the river morphological change to be studied. Using the computed river topographies, the model was used also to assess the water levels at different values of the discharges in different years.

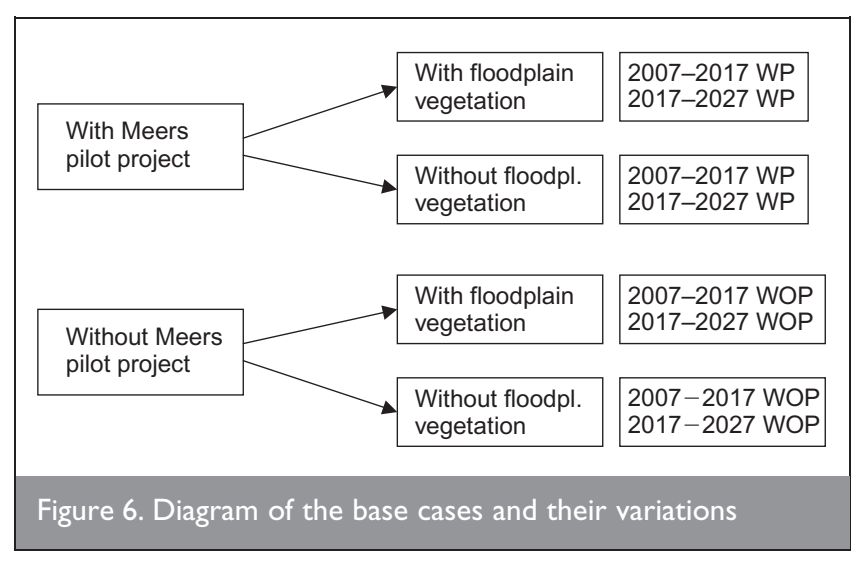




\section{RESULTS}

\section{I. Effects of the Meers pilot project on water levels}

The effects of the pilot project on water levels were derived for a flood characterised by a discharge of $3000 \mathrm{~m}^{3} / \mathrm{s}$, having a return period of 100 years, and for a flood characterised by a discharge of $1680 \mathrm{~m}^{3} / \mathrm{s}$, having return period of 1 to 3.5 years (medium flood).

Figure 7 shows the predicted water levels in 2007 and 2027 in the two cases WP and WOP at a discharge of $3000 \mathrm{~m}^{3} / \mathrm{s}$, calculated using the computed 2007 and 2027 river topographies and assuming vegetated floodplains (vegetation cover 2007). The model results for the year 2007 show that the execution of the pilot project led to local decreases as well as local increases of water levels that are not larger than $10 \mathrm{~cm}$, so that the reach-averaged effect of the project on water levels is negligible. Water slopes vary due to strong variations in bed level (Figure 7). A similar trend was observable for the situation in 2027.

The project does not appear effective in reducing water levels at high floods. The floodplain restriction (bottleneck) located a short distance downstream of the restored area (Figure 5) produces important backwater effects. The average water level increase in the pilot project area due to the downstream bottleneck was quantified as $0.5 \mathrm{~m}$ by running the hypothetical case in which the bottleneck is removed by floodplain widening and removal of internal dykes.

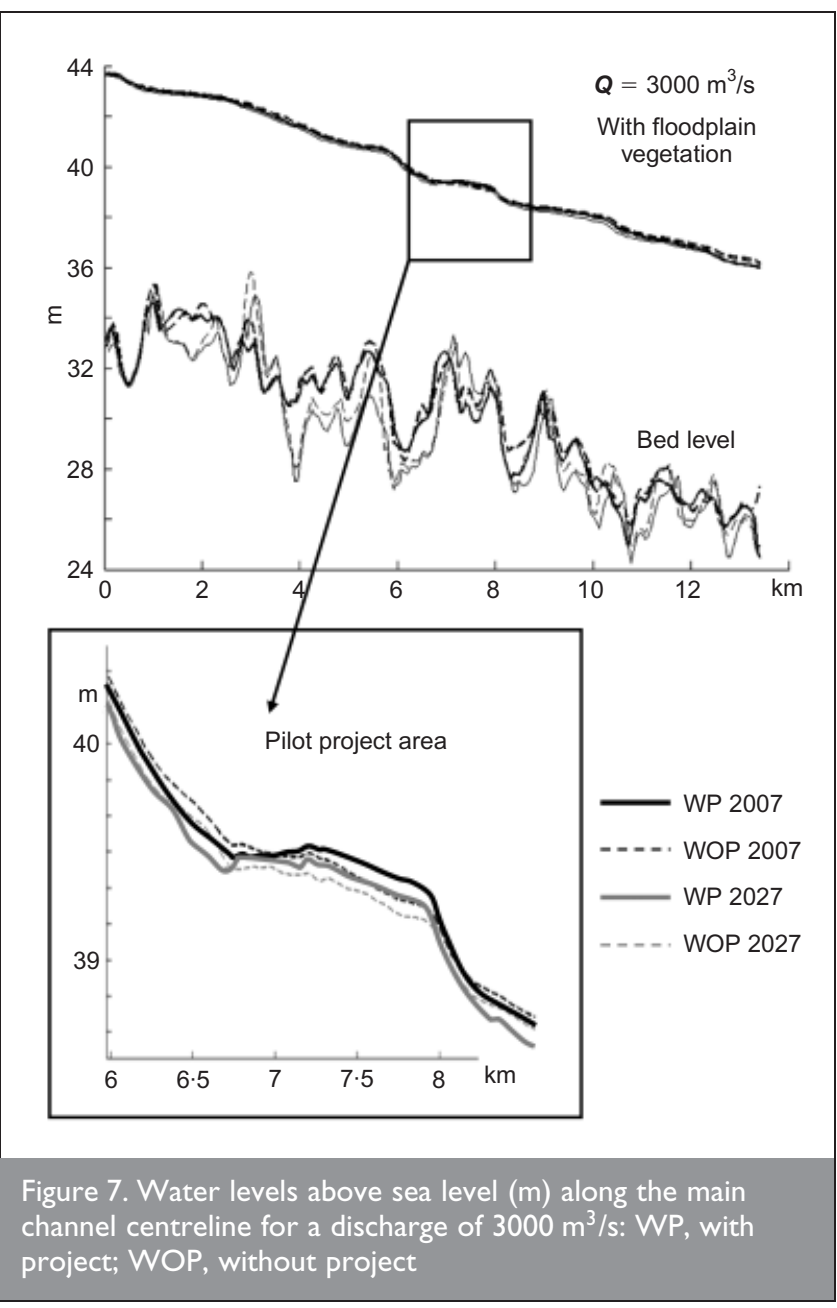

Figure 8 shows the computed water levels in 2007 and 2027 in the two cases WP and WOP for a discharge of $1680 \mathrm{~m}^{3} / \mathrm{s}$ (medium flood). In this case the computations also used the computed 2007 and 2027 river topographies and assumed vegetated floodplains. For this value of the discharge, the Meers pilot project lowers the water levels by about $30 \mathrm{~cm}$ on average in both 2007 and 2027. In this case the backwater effects created by the downstream floodplain restriction are smaller. Therefore, the pilot project is more effective in reducing medium flood levels than high flood levels.

In general, for all cases the water and bed levels became lower with time over the period simulated. This was due to progressive bed degradation (about $10 \mathrm{~cm}$ in 20 years), which can be attributed to the extraction of sediment that was carried out for the execution of the Meers pilot project.

\subsection{Effects of floodplain vegetation on water levels} The effects of floodplain vegetation on water levels were derived for both the high-flood discharge of $3000 \mathrm{~m}^{3} / \mathrm{s}$ and for the medium-flood discharge of $1680 \mathrm{~m}^{3} / \mathrm{s}$.

Figure 9 shows the computed water levels for the discharge of $3000 \mathrm{~m}^{3} / \mathrm{s}$ after execution of the Meers pilot project (case WP). The averaged differences in water levels between the cases with and without floodplain vegetation were estimated as $0.88 \mathrm{~m}$ for the year 2007 and $0 \cdot 83$ for the year 2027 .

Figure 10 shows the computed water levels for the discharge of $1680 \mathrm{~m}^{3} / \mathrm{s}$. In this case floodplain vegetation increases the water levels by about $0 \cdot 70 \mathrm{~m}$ both in 2007 and 2027 .

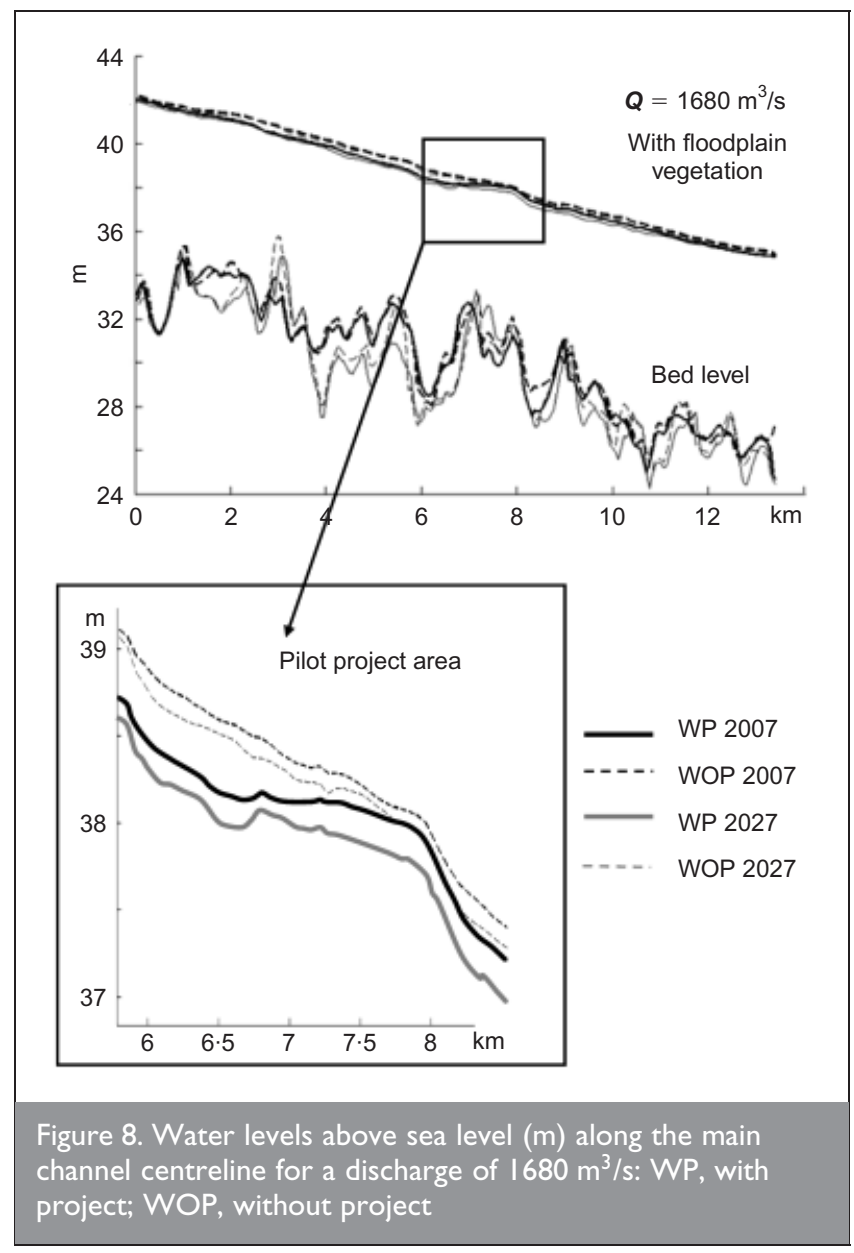




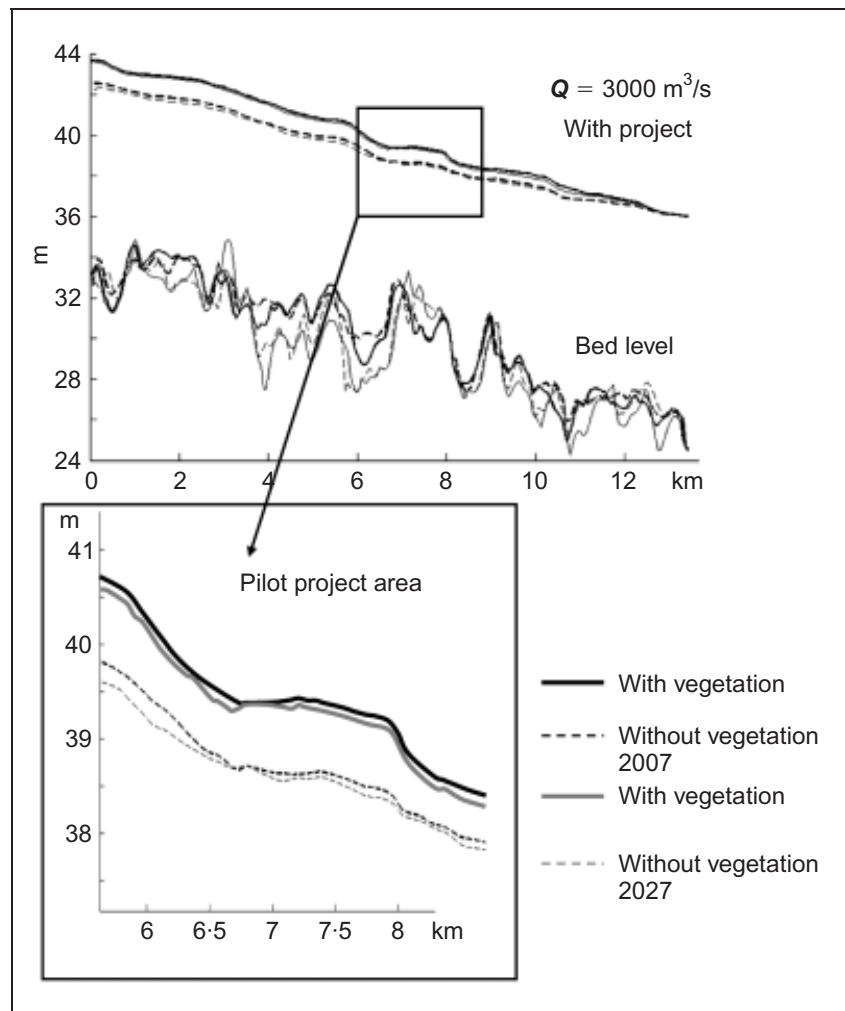

Figure 9. Water levels above sea level $(\mathrm{m})$ along the main channel centreline for a discharge of $3000 \mathrm{~m}^{3} / \mathrm{s}$

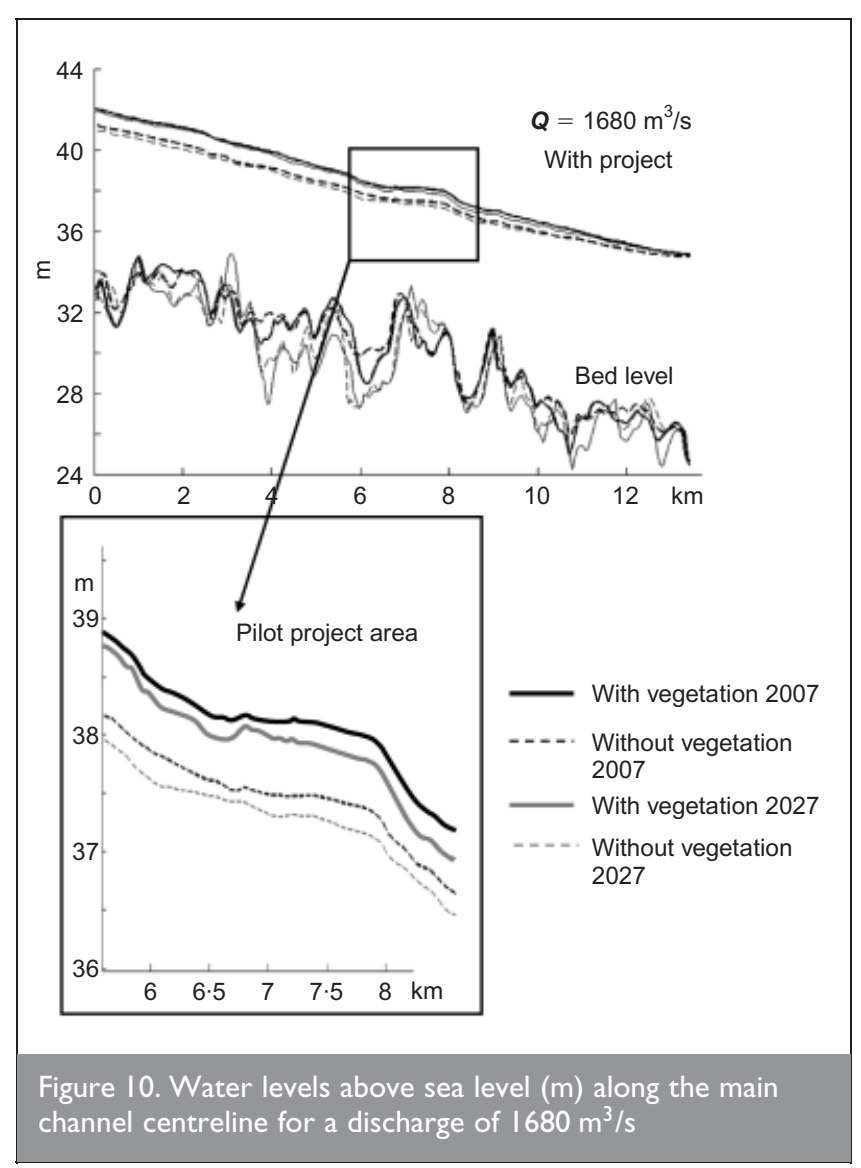

\subsection{Effects of floodplain vegetation on morphological changes}

The effects of vegetation on morphological changes were assessed for the period 2007-2027, including the Meers pilot project (WP). Table 6 presents the variations in bed level at different places computed with and without floodplain vegetation for the period 2007-2017 and for 2017-2027, whereas Figure 11 identifies the places considered in the table.

The results show that in the first 10 years the morphological changes are larger than in the second 10 years. Accumulation of material takes place in the excavated area and along the inner bends, upstream and downstream of the restored area. Erosion occurs at the outer bends. Erosion dominates the main river channel immediately downstream of the excavated area. This type of behaviour can be explained by some simple theoretical considerations. The Meers pilot project mainly consisted in deepening the right-side floodplain close to the river main channel, which can be regarded as local widening, since the main channel width increased from 80 to $230 \mathrm{~m}$, approximately (Figure 12). Considering that the bed material is constituted by loose sand and gravel, we can assume that for discharges larger or equal to $1000 \mathrm{~m}^{3} / \mathrm{s}$ locally the sediment transport is equal to the sediment transport capacity. This is in turn a function of flow velocity. Shortly after the execution of the project, namely before the river reaches a new stable configuration, the water flow slightly accelerates just upstream of the widened part, which results in local bed erosion. The flow suddenly decelerates at the location of the intervention, due to abrupt widening, which causes sedimentation. In the widened part the flow slightly decelerates further, which causes even more sedimentation. Finally, at the downstream end of the intervention the water flow suddenly accelerates, because the river returns to its natural width, which causes local bed erosion. Due to local deposition, in the widened area the river gradually returns to a configuration that is close to its initial state, reducing the effects of the restoration and creating the need for a maintenance programme.

Figures 13 and 14 show the bed level changes of the river cross-section at the location of the project computed for the period 2007-2027, without and with floodplain vegetation, respectively. At the right river side it is possible to recognise the excavated floodplain next to the main river channel (deepest area). Deposition in the excavated area evolves in the form of a sedimentation wave propagating outwards.

For the case with floodplain vegetation, the volume of material accumulated inside the excavated area at the end of the period is about $87000 \mathrm{~m}^{3}$, which represents $20 \%$ of the total excavated volume $\left(435000 \mathrm{~m}^{3}\right)$. Without floodplain vegetation the volume of accumulated material is about $66000 \mathrm{~m}^{3}$, which represents $15 \%$ of the total excavated volume.

Main channel bed degradation takes place in both cases. Without vegetation the bed level decreases on average by about $10 \mathrm{~cm}$, with vegetation by $20 \mathrm{~cm}$. The enhanced bed degradation is due to the fact that vegetation concentrates the flow in the main channel, which increases the erosive power of the flow.

\section{DISCUSSION}

Lack of historical data, in particular on river bed topography, impeded thorough verification of the morphological model, which is a classic problem in river engineering. In this case, the results should be interpreted with care, with a qualitative rather 


\begin{tabular}{|c|c|c|c|c|c|}
\hline \multirow[t]{2}{*}{ Point } & \multirow[t]{2}{*}{ Description } & \multicolumn{2}{|c|}{ Period 2007-2017 } & \multicolumn{2}{|c|}{ Period 2017-2027 } \\
\hline & & $\begin{array}{l}\text { With floodplain } \\
\text { vegetation }\end{array}$ & $\begin{array}{l}\text { Without floodplain } \\
\text { vegetation }\end{array}$ & $\begin{array}{l}\text { With floodplain } \\
\text { vegetation }\end{array}$ & $\begin{array}{l}\text { Without floodplain } \\
\text { vegetation }\end{array}$ \\
\hline $\mathrm{I}-\mathrm{L}$ & Inner bend upstream of restored area & +4 & $+4 \cdot 1$ & +3 & $+3 \cdot 5$ \\
\hline$I-R$ & Outer bend upstream of restored area & $-4 \cdot 8$ & $-6 \cdot 5$ & -3 & $-2 \cdot 8$ \\
\hline $2-\mathrm{L}$ & Inner bend upstream of restored area & +4 & +4 & +4 & +3.5 \\
\hline $2-R$ & Outer bend upstream of restored area & -6 & $-5 \cdot 5$ & -3 & $-3 \cdot 1$ \\
\hline $3-R$ & Inner bend restored area & +4.5 & +4 & $+3 \cdot 2$ & +3 \\
\hline 3-L & Outer bend restored area & $-3 \cdot 8$ & -5 & $-3 \cdot 5$ & $-3 \cdot 1$ \\
\hline $4-R$ & Inner bend downstream of restored area & +1.8 & $+2 \cdot 5$ & +2 & +1.8 \\
\hline $5-R$ & Inner bend downstream of restored area & $+4 \cdot 2$ & $+4 \cdot 1$ & +4 & +3 \\
\hline
\end{tabular}

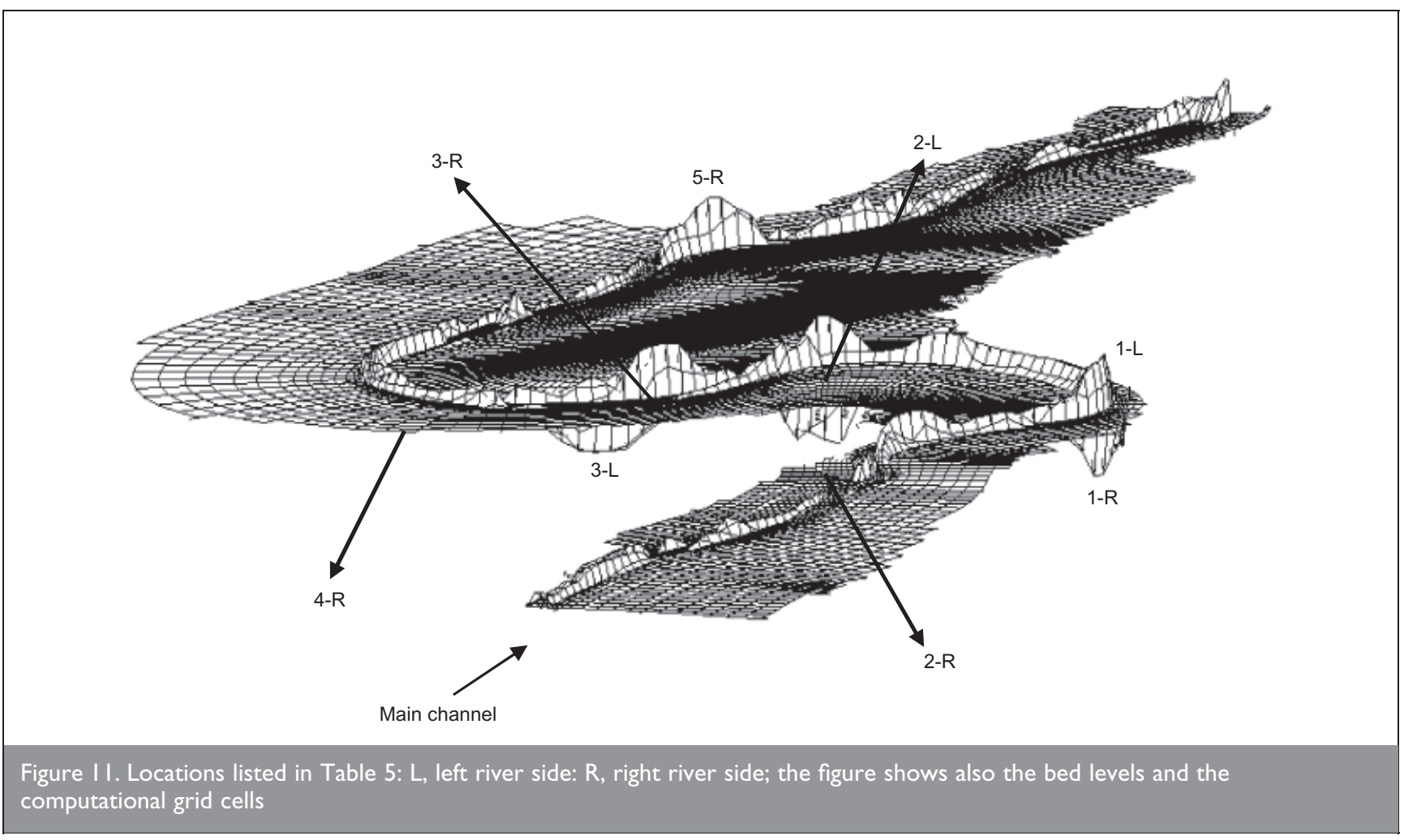

than quantitative approach. Although quantitative results are presented, these should be interpreted in terms of 'positive' or 'negative' changes.

The investigations were restricted to the effects of the pilot project, carried out over a short reach, on water levels. It could be worth investigating whether carrying out this type of intervention over a longer reach would be more effective in lowering the water levels at high floods and whether this could be an alternative to removing a downstream bottleneck.

Various aspects of vegetation management, such as the optimal frequency of plant cutting, can be studied only if growth and succession of vegetation are taken into account and properly modelled. This was not done in the present study. Nevertheless, the results show the need for floodplain vegetation management in the study area.

\section{CONCLUSIONS}

The Meers pilot project is effective in lowering the local water levels $(-30 \mathrm{~cm})$ at medium floods, characterised by a return period of 1 to 4 years for at least 20 years, but not at high floods, having a return period of about 100 years. For high floods, backwater effects caused by a downstream floodplain restriction, acting as a bottleneck, dominate the river water levels. Removal of this bottleneck, either by locally enlarging the floodplains or by channel deepening, therefore appears more effective in reducing flooding risk in the area than interventions such as lowering of floodplains carried out over a short reach and where floodplains are large already.

Floodplain vegetation was found to significantly increase the water levels during floods if compared with the hypothetical case of bare floodplains. In the specific case of the pilot project, the effects of vegetation in increasing water levels $(+0.7 \mathrm{~m}$ for medium floods and $+0 \cdot 8 \mathrm{~m}$ for high floods) is larger 


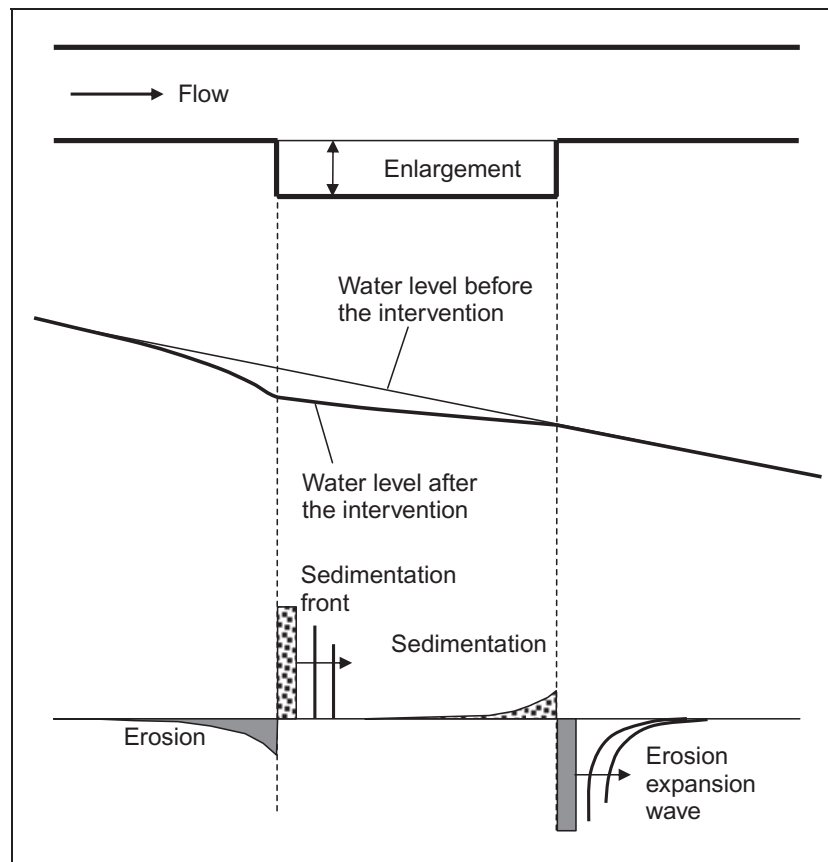

Figure 12. Scheme showing the short-term river response to channel widening (subcritical flow)

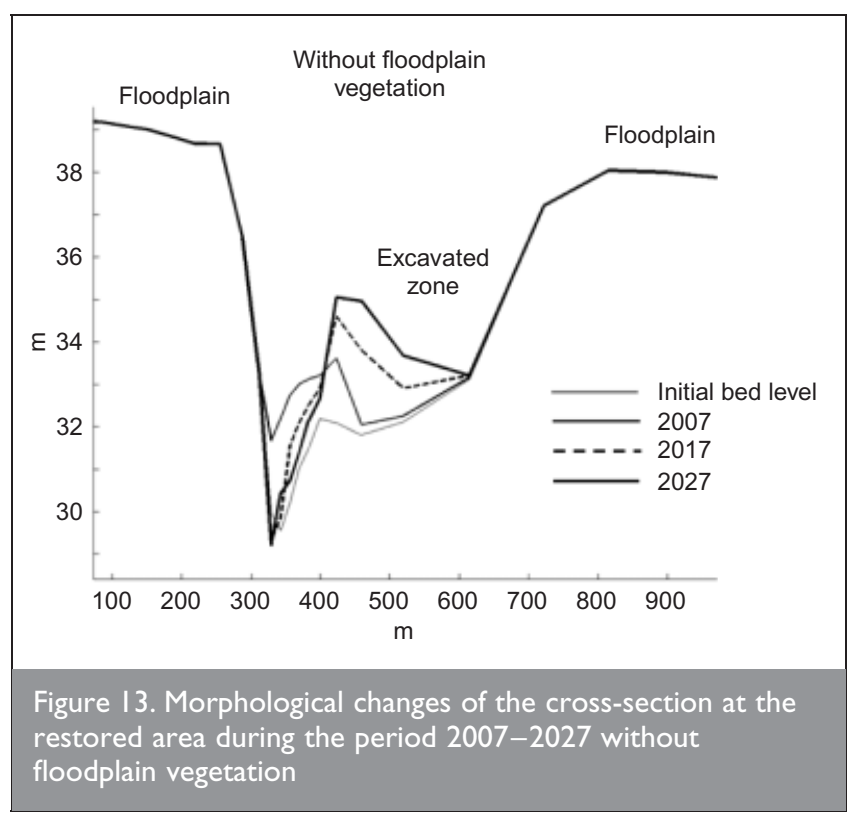

than the lowering effects of the restoration project. This means that the effects of the pilot project may soon vanish if vegetation is allowed to grow uncontrolled on floodplains.

Both sedimentation and vegetation development on floodplains are known to limit the lifetime of this type of project, in which flood risk reduction has the priority. We found the combination of the two developments to have stronger effects than the effects of sedimentation and vegetation alone, because floodplain vegetation enhanced the sedimentation in the excavation pit. Even in this river of low sediment transport, the vegetation-induced sedimentation shortened the project lifetime by approximately $5 \%$.

In all the simulated cases the results show general long-term river bed degradation upstream and downstream of the pilot

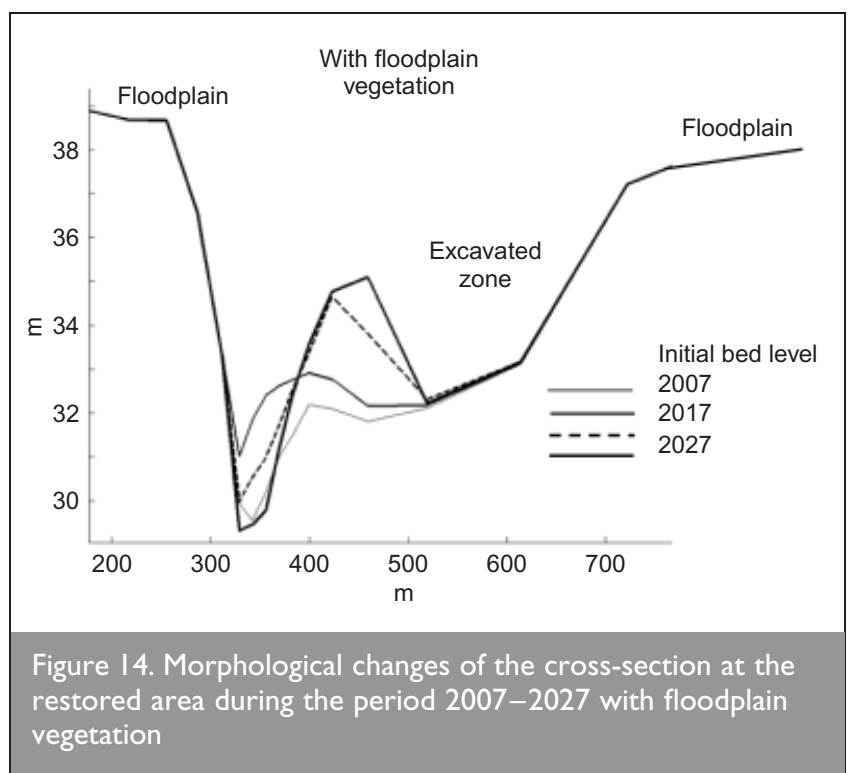

project. This can be attributed to the extraction of sediment that is related to the intervention, since the excavated volume was about eight times the yearly sediment transport of the river. Without floodplain vegetation the averaged main channel bed degradation was found to be about $10 \mathrm{~cm}$; with vegetation $20 \mathrm{~cm}$. The enhanced bed degradation is due to the fact that vegetation concentrates the flow in the main channel, which increases the erosive power of the flow. The effects of the removal of sediment from the river system should also be estimated before undertaking this type of project and could have a larger influence still when such restorations are carried out on longer reaches.

\section{ACKNOWLEDGEMENTS}

The research was carried out within the NCR framework and funded by the Delft Cluster Project (the Netherlands) 'Safety against flooding'. The authors wish to thank Dr Erik Mosselman, Dr Kees Sloff, Dr Bert Jagers, Dr Migena Zangonjolli and all the colleagues from the River Engineering Department of Deltares for their collaboration during the modelling process. Special thanks are due to Mr Udo Boot (Ministry of Public Works, Transports and Water Management, Limburg) for his kind cooperation. Finally, the authors wish to thank Professor Nigel Wright (UNESCO-IHE) for his support and advice.

\section{REFERENCES}

Bagnold RA (1966) An Approach to the Sediment Transport Problem from General Physics. United States Department of the Interior, US Geological Survey, Paper 422-I, 37 pp, Washington, DC.

Baptist MJ (2005) Modelling Floodplain Biogeomorphology. PhD thesis, Delft University of Technology, the Netherlands.

Blanckaert K, Glasson L, Jagers HRA and Sloff CJ (2002) Quasi3D simulation of flow in sharp open-channel bends with horizontal and developed bed topography. In Shallow Flows (Jirka GH and Uijttewaal WSJ (eds)). Taylor and Francis, London, UK, pp. 310-315.

Brookes A (1990) Restoration and enhancement of engineered river channels: some European experiences. Regulated Rivers: Research and Management, 5(1), 45-56.

Buijse AD, Coops H, Staras M et al. (2002) Restoration 
strategies for river floodplains along large lowland rivers in Europe. Freshwater Biology 47(4): 867-887.

Carollo FG, Ferro V and Termini D (2002) Flow velocity measurements in vegetated channels. Journal of Hydraulic Engineering 128(7): 664-673.

Corenblit D, Tabacchi E, Steiger J and Gurnell A (2007) Reciprocal interactions and adjustments between fluvial landforms and vegetation dynamics in river corridors: a review of complementary approaches. Earth Science Reviews 84(1-2): 56-86.

Elgersma AM (1998) Primary forest succession on poor sandy soils as related to site factors. Biodiversity and Conservation 7(2): 193-206.

Franz EH and Bazzaz FA (1977) Simulation of vegetation response to modified hydrologic regimes: a probabilistic model based on niche differentiation in a floodplain forest. Ecology 58(1): 176-183.

Hupp CR and Osterkamp WR (1996) Riparian vegetation and fluvial geomorphic processes. Geomorphology 14(4): $277-$ 295.

Ikeda S (1982) Lateral bed slope transport on side slopes. Journal of the Hydraulics Division 108(11): 1369-1373.

Johnson WC (1998) Adjustment of riparian vegetation to river regulation in the Great Plains, USA. Wetlands 18(4): $608-$ 618.

Klaassen GJ (1981) Morphological Phenomena Common Meuse River. WL Delft Hydraulics, Delft, the Netherlands, Report R863.

Klaassen GJ, Lambeek J, Mosselman E, Duizendstra HD and Nieuwenhuijzen ME (1998) Re-naturalization of the Meuse River in the Netherlands. In Gravel-bed Rivers in the Environment (Klingeman PC, Beschta RL, Komar PD and Bradley JB (eds)). Water Resources Publ., Highlands Ranch, C0, USA, pp. 655-674.

Lesser GR, Roelvink JA, Van Kester JATM and Stelling GS (2004) Development and validation of a three dimensional morphological model. Coastal Engineering 51(8-9): 883915.

Merritt DM and Cooper DJ (2000) Riparian vegetation and channel change in response to river regulation: a comparative study of regulated and unregulated streams in the Green River Basin, USA. Regulated Rivers: Research and Management 16(6): 543-564.

Meyer-Peter E and Müller R (1948) Formulas for bed load transport. Proceedings of the 2nd IAHR Congress, Stockholm, Sweden, 2, 39-64.

Olsthoorn AA and Tol RSJ (2001) Floods, Flood Management and Climate Change in the Netherlands. Institute for Environmental Studies, Free University, Amsterdam, the Netherlands, Report R-01/04.

Partheniades E (1965) Erosion and deposition of cohesive soils. Journal of the Hydraulic Division 91(HY1): 105-139.

Pfister L, Kwadijk J, Musy A, Bronstert A and Hoffman L (2004) Climate change, land use change and runoff prediction in the Rhine-Meuse basins. River Research and Applications 20(3): 229-241.

Raat AJP (2001) Ecological rehabilitation of the Dutch part of the River Rhine with special attention to the fish. Regulated Rivers: Research and Management 17(2): 131-144.

Sharef B (2006) Numerical Modelling with Graded Sediment for 2D Morphological Changes for Pilot Project Meers (Common Meuse) WSE-HERBD. MSc thesis, UNESCO-IHE, Delft, the Netherlands.

Struiksma N, Olesen KW, Flokstra C and De Vriend HJ (1985) Bed deformation in curved alluvial channels. Journal of Hydraulic Research 23(1): 57-59.

Thorne CR (1990) Effects of vegetation on riverbank erosion and stability. In Vegetation and Erosion (Thornes JB (ed.)). Wiley, Chichester, pp. 125-144.

Tsujimoto T (1999) Fluvial processes in streams with vegetation. Journal of Hydraulic Research 4(6): 789-803.

van der Wegen M, Wang ZB, Savenije HHG and Roelvink JA (2008) Long-term morphodynamic evolution and energy dissipation in a coastal plain, tidal embayment. Journal of Geophysical Research, Earth Surface. 113, F03001, pp. 22, doi: 10.1029/2007JF000898.

van Rijn LC (1993) Principles of Sediment Transport in Rivers, Estuaries and Coastal Seas, Part 1. Aqua Publications, Blokzijl, the Netherlands, p. 111, NUGI 186/831.

Villada Arroyave JA (2008) Influence of Vegetation on the Long Term Morphological Processes in the Common Meuse River. MSc thesis, UNESCO-IHE, Delft, the Netherlands.

\section{What do you think?}

To discuss this paper, please email up to 500 words to the editor at journals@ice.org.uk. Your contribution will be forwarded to the author(s) for a reply and, if considered appropriate by the editorial panel, will be published as discussion in a future issue of the journal.

Proceedings journals rely entirely on contributions sent in by civil engineering professionals, academics and students. Papers should be 2000-5000 words long (briefing papers should be 1000-2000 words long), with adequate illustrations and references. You can submit your paper online via www.icevirtuallibrary.com/content/journals, where you will also find detailed author guidelines. 